回折の強度が增強されることが認められたので, これが ふつうの加水分解醭素などによっては分解されにくい， 抵抗性のつよい物質から構成されていることが明らかに なった(1i).

$9.3 \AA$ と $9.8 \AA$ の回折は, 既知の物質のうちでは keratin に存在することが知られているので, 純化した spore coat のX線回折図を, Astbury および Street(15) が羊毛 keratin について報告している回折像と比較した ところ (第 3 図), 両者は非常によく一致し, $15 \AA$ から $2.6 \AA$ の範囲内では, 羊毛 keratin 飞存在する $\alpha$ 型と $\beta$ 型の回折のほとんどすべてが spore coat に見いださ れたが，この事実は， spore coat が，羊毛 keratin と ほ济同じ結晶構造ともっていることを示している（化学
分析の結果からも, spore coat は keratin 類似のタン パク質から構成されていることが推定された) ${ }^{(14)}$.すな わち，一般に羊毛 keratin などの k-m-e-f 群タンパク 質に見られる， $\alpha$-helix をさらにねじった $\alpha$-keratin 型の構造（coiled-coil 型構造）と， $\alpha$-keratin を繊維軸 の方向にひきのばしたときに現われるジグザグ平面構造 である $\beta$-keratin 型構造とが, spore coat には同時に 存在することがわかる.

ただ，回折の強度から判断すると, spore coat 中で は, $\alpha$-keratin 型構造より $\beta$-keratin 型の構造のほう がいくらか優勢であると推定される。なお, 最初に述べ た $9.8 \AA$ の鋭い反射は $\alpha(001), \beta(001)$ のものであ り, $9.3 \AA$ のそれは $\beta$ (rectangular) のものであった.

$$
\text { 〈生物コーナー> }
$$

\section{ニワトリ輸卵管における ムコ多糖類の生合成}

鈴 木

\section{旺}

卵とい总ば、ニワトリの卵の代名詞になるほど，それ はわれわれと深い結びっきをもっている。しかし，これ は主として食品としての結びっきであって, 卵を特異的 なタンパク質や多糖類の集合体とみて，タンパク質生合 成や多糖生合成の一般的かつ基本的研究のための材料に しょうとする陚みは少ないように思う。卵白をそのまま CM-セルロースの カラムクロマトグラフィーで分画す ると,ovalbumin, conalbumin, ovomucoid, ovomucin, lysozyme, avidin, flavoprotein など, 多数のタンパ ク質成分に分かれる (Feeney)。これらの大部分が単純 タンパク質ではなく糖タンパク質 (glycoprotein), す なわち, ペプチド鎖のセリン, スレオニンの水酸基やア スパラギン,グルタミンの酸フミド基から糖の枝が出た 構造をとるもので占められている. とくに albumin の 糖とアミノ酸残基の結合様式は詳しく研究されて, N( $\beta$-aspartyl)-glycosylamine 型であることが立証され ている (Neuberger).

卵殼膜（殼の内側についているレース状の膜）もまた 特色のある数種の糖タンパク質からできている.アミノ 酸組成はオルニチンの存在を除いて普通のタンパク質と 大差はないが, 糖成分はアラビノース, グルコース; ガ ラクトース, マンノース, フコース, グルコサミン, ガ ラクトサミン,グルクロン酸と多くの種類のものをもっ
ている(坂部, 鈴木).

ニワトリの輸卵管は，これら多種多様の糖タンパク質 を生合成する器官である. それは径 $1 \sim 2 \mathrm{~cm}$, 長さ 40 $\mathrm{cm}$ ほどの伸長性ある管で, 長軸に沿って切り開いてみ ると，内側には輸卵管を 3 つの部分に区別する境界をみ ることができる，私どもは現在まで 5,000 羽をこ觉る ほどの輸畉管を処理してきたが, 卵の存在している位置 と卵の完成度との間には見事な対応関係が観察できた。 まず卵栄飞最も近い部分 $(25 \mathrm{~cm})$ 飞存在する卵は，卵 白はできているが膜や款はつけていない。これにつづく 細くて短かい部分 (isthmus と呼ぶ；8cm) に入った 卵は，卵白の上に膜をつけている，として最後の子宮部 分 $(7 \mathrm{~cm})$ 飞進んだ畉は殼をかぶって注淁完全な形をと とのえている。このようにして，卵白，卵款膜，卵殸は 輸卵管の中を卵が移動するにつれて，それぞれ異なる部 分で分業的に合成されることが明らかとなった。

さて，糖タンパク質とかムコペプチドなどと一般に呼 ばれている生体高分子の中で, その生合成メカニズムの 研究が最も進んでいるのはバクテリアの細胞壁である. この領域に打ける最初の重要な発見は，1949年 Parkに よるペニシリン接触 S. aureus からの新ウリジンスクレ オチドの単離同定であったことは，すでに有名な話であ る. その構造は, ムラミル-L-アラニルーDーグルタミルー LーリシルーD-アラニル-Dーアラニンといら糖ペプチドがウ リジンジリン酸 (UDP) の末端リン酸残基に結合したも のであるが，この糖ペプチドの組成は，一般にグラム陽 性菌の細胞壁を構成する糖ペプチドと非常によく似てい る.この構造の近似性ということが, Park のヌクレオ チドは細胞壁の生合成前駆体であるうといら仮説を導き 


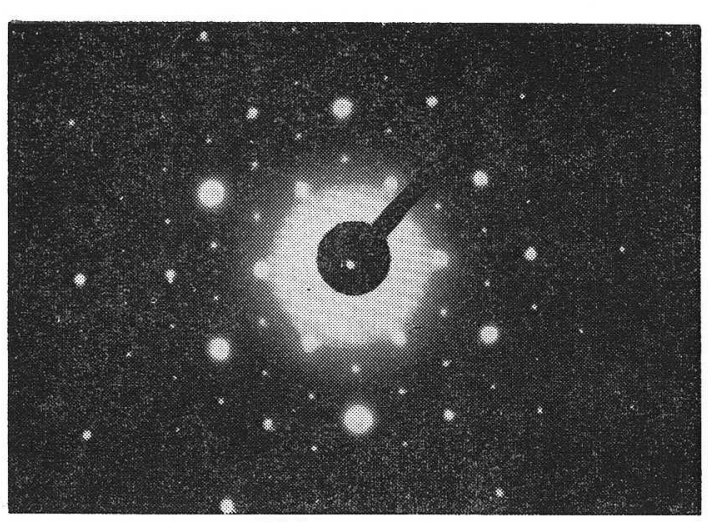

第 4図 Bacillus subtilis の spore coat の電子線回折図
つぎに、この結晶構造をさらに別の視野から検討する ために，その電子線回折を試みた。すなおた，さきに第 2 四に示した spore coat の断片を酷素処理によって純 化した後，制限視野の下で電子線回折した結果が第 4 図 であるが，この回折像から spore coatを構成する結晶 は単結晶であり，その回折図型は hexagonal タイプで あることがわかる。

第 2 図にも見られるよらに，回折の試料として用いた spore coat の断片はフィルム状の element からできて いるので，電子線はこのフィルムの平面，つまり $a, b$ 軸方向に垂值に入射していることになる．結晶が hexa gonal であると仮定して，このデータとX線回折の結果 とから unit cell の dimension を計算すると, $\mathrm{c}_{0}=9.8$
出したのである。この仮説が生まれて約 10 年, Park のヌクレオチドと UDP-アセチルグルコサミンを基質に し，細胞膜成分としてのリピドを添加した条件下で細胞 壁ムコペプチドが試験管内で合成されることが示され， この問題もようやく完成期に入ろらとしている (Strominger).

ところで，このメカニズムをそのままの形で動物細胞 膜の生合成にあてはめることはできないまでも，どらら も糖タンパク質として類似構造をとる点から考えて, 畉 殼膜の生合成中間体にも Park のヌクレオチドのように， 膜成分の一部が活性化された形の前駆体を想定すること は無謀ではなからう。もしこのよらな中間体があれば, それは輸卵管の細胞の中に多かれ少なかれプールされて いるのではないか？もちろん，生会成中間体が，すべ てプールされているという考光は䛊りを含んでいる.

しかし，とにかくこの単純な推理のもとに行なわれた一 連の化学的仕事の結果, 輸卵管の isthmus 部分には, 今までほかで見いだされたことのない珍しいスクレオチ ドがプールされていることが明らかになったのである。 UDP-アセチルガラクトサミンー4-硫酸, UDP-アヒチル グルコサミンー6-フォスフォガラクトース, UDP-アセチ ルグルコサミンー6-フコースの 3 種が代表的なもので量 も多い.これら UDP と結合し「活性化」された型の糖 成分は, 前述の卵款膜糖成分とよく一致して未り，この 構造類似性は上記スクレオチドがいずれる畉殼膜生合成 の中間体であることを暗示している．その直接的証明は， 現在私どもが最も力をいれて追求しつつある問題である が，もっと一般的に糖タンパク質といらカテゴリーに入 る生体高分子の生合成に, ヌクレオチドと結合して「活
性化された」二糖や三糖を中間体として想定することが 可能のように思われてきた。というのは, 輸卵管以外に も，たとえば乳腺のように活発な糖タンパク質生合成を 営むところ，あるい㥒そのものの中に，ちょらどその 糖タンパク質の糖残基を糖配列まで含めて写しとったよ らな UDP-oligosaccharide 化合物が見いだされるよう になったからである（小幡, Roseman ら).

私どもが輸卵管にとり組んですすでに 5 年をこしてし まった。この期間の大半は前記ヌクレオチドの単離と構 造決定に費やされたが，生合成系そのものの酵素学的研 究も意っていたわけではない，しかし輸卵管は卵を合成 するだけでなく，一方では自らの組織を維持するための 糖タンパク質合成をも営んでいる。すりつぶした標品に よる酵素活性は意外に複雑である.たとえば UDPーアセ チルガラクトサミン-4-硫酸の卵款膜へのとりこみを目 標にして ${ }^{35} \mathrm{~S}$ を利用した一連の仕事は, 結局, 輸卵管自 身の結合組織として豊富に存在する, コンドロイチン硫 酸の合成系をとらえることに終ってしまったこのム 多糖もアセチルガラクトサミンー4-硫酸を成分として含 んでいるが, UDP-アセチルガラクトサミンー4-硫酸を 経由して生合成されることはない，これは軟骨を材料に した他の研究者の結論とも一致する (Lipmannら).

細胞は卵合成のための糖タンパク質合成系と; 自らの 組織形成のための糖タンパク質合成系とを，ぞのように 区別乙制御しているのだろらか、「卵はどうしてできる の?」といら子供のような好奇心は問題追求意欲の原動 カにはなり得たが, 現在最も必要なものはもしろ，いを 一歩の前進をはばんでいる障害をとり除くための大人の 知恵と能力である。

(名古屋大学理学部化学教室) 